\title{
A NEW GENUS OF THE SUBFAMILY CUBACUBANINAE (INSECTA: ZYGENTOMA: NICOLETIIDAE) FROM CAVES IN SOUTH-CENTRAL AND SOUTHWESTERN USA
}

\author{
Luis Espinasa', Stephen Furst'1, Thomas Allen², and Michael E. Slay ${ }^{3}$
}

\begin{abstract}
The genus Speleonycta is erected, and S. ozarkensis, n. sp., is described and separated from other species of the subfamily Cubacubaninae. The type species was collected from several caves in the Ozark Plateau, while two more species, collected from a cave in Arizona and from a cave in California, remain under study. Morphology and preliminary analyses using histone DNA indicate that the new genus may be related to Texoreddellia, another nicoletiid from caves of Texas and northern Mexico.
\end{abstract}

\section{INTRODUCTION}

The subfamily Cubacubaninae in the hexapod family Nicoletiidae of silverfish is among the most important and common representatives of cave-adapted fauna in the Neotropics (Espinasa and Giribet, 2009), but they have a limited presence in caves of northern latitudes. Texas, where a species complex of at least six species in the genus Texoreddellia has been described (Espinasa and Giribet, 2009), appeared to be the northern limit of their distribution.

Nicoletiid specimens have been collected from several Ozark caves in Arkansas and Oklahoma. These collections are part of a larger and ongoing effort by The Nature Conservancy to conduct a comprehensive cave-fauna inventory, particularly in the caves of the southern Ozarks. These specimens represent a new genus of Nicoletiidae related to Texoreddellia. Despite being collected so sporadically, members of the new genus may actually have a wide distribution throughout the caves of the southwestern United States.

\section{Materials And Methods}

Dissections of holotypes were made with the aid of a stereo microscope and mounted as fixed preparations with Hoyer's solution. The remaining samples were left in a vial with ethanol. Illustrations were made with the aid of a camera lucida attached to a microscope. Specimens will be deposited in a collection at the American Museum of Natural History in New York.

Genomic DNA samples were extracted using Qiagen's DNEasy Tissue Kit by digesting a leg in lysis buffer from the paratype collected from Uno Cave, and from Texoreddellia texensis (Ulrich, 1902), T. coahuilensis Espinasa and Giribet, 2009, T. aquilonalis Espinasa and Giribet, 2009, and a specimen of the T. texensis species complex. Amplification and sequencing of the histone fragment was done as in Espinasa and Giribet (2009) following standard protocols and primers used in the past for nicoletiids. Chromatograms obtained from the automated sequencer were read and contigs made using the sequence editing software Sequencher 3.0. External primers were excluded from the analyses. Sequences were aligned with ClustalW2, and phylogram trees were obtained using PAUP 4.0 for neighbor-joining and parsimony-bootstrap method using heuristic search with 1,000 replicates.

\section{RESUlts AND DisCUSSION}

Molecular data were obtained for one terminal from the specimen of Uno Cave (Table 1). The histone fragment was 328 bp long (primers excluded). Alignment with other species of the Cubacubaninae with ClustalW2 was trivial, as no gaps were needed. Both neighbor-joining and parsimony-bootstrap 50\%-majority-rule consensus trees (Fig. 1A, B) showed the new species within a monophyletic group (90\% bootstrap) with Texoreddellia. As such, the new species is granted exclusion from other genera of the Cubacubaninae. Nonetheless, the new species cannot be included within the Texoreddellia genus as it lacks the scales diagnostic of genus Texoreddellia. Furthermore, its sequence differs considerably (average of $52 \mathrm{bp} ; 15.8 \%$ ) from the other species of Texoredellia, which is equivalent to the differences found among other genera of the Cubacubaninae, such as between Squamigera, Prosthecina, and Anelpistina (Fig. 1A). The specimens also have a unique appearance of the genital area not found in any other described species of the Cubacubaninae. Therefore, a new genus is proposed.

\section{Speleonycta New Genus \\ Espinasa, Furst, Allen, and Slay}

Diagnosis: A member of the subfamily Cubacubaninae without scales. Urosternum VIII of male flat posteriorly, without emarginations or projections in between the stylets of this segment. Paramera with a distal semi-eversible

\footnotetext{
${ }^{1}$ School of Science, Marist College, 3399 North Road, Poughkeepsie, NY 12601, luis.espinasa@marist.edu

${ }^{2}$ Academy of Natural Sciences, Philadelphia, PA

${ }^{3}$ Arkansas Field Office, The Nature Conservancy, 601 North University Avenue, Little Rock, AR 72705
} 
A new genus of the subfamily Cubacubaninae (Insecta: Zygentoma: Nicoletildae) from caves in south-central and SOUTHWESTERN USA

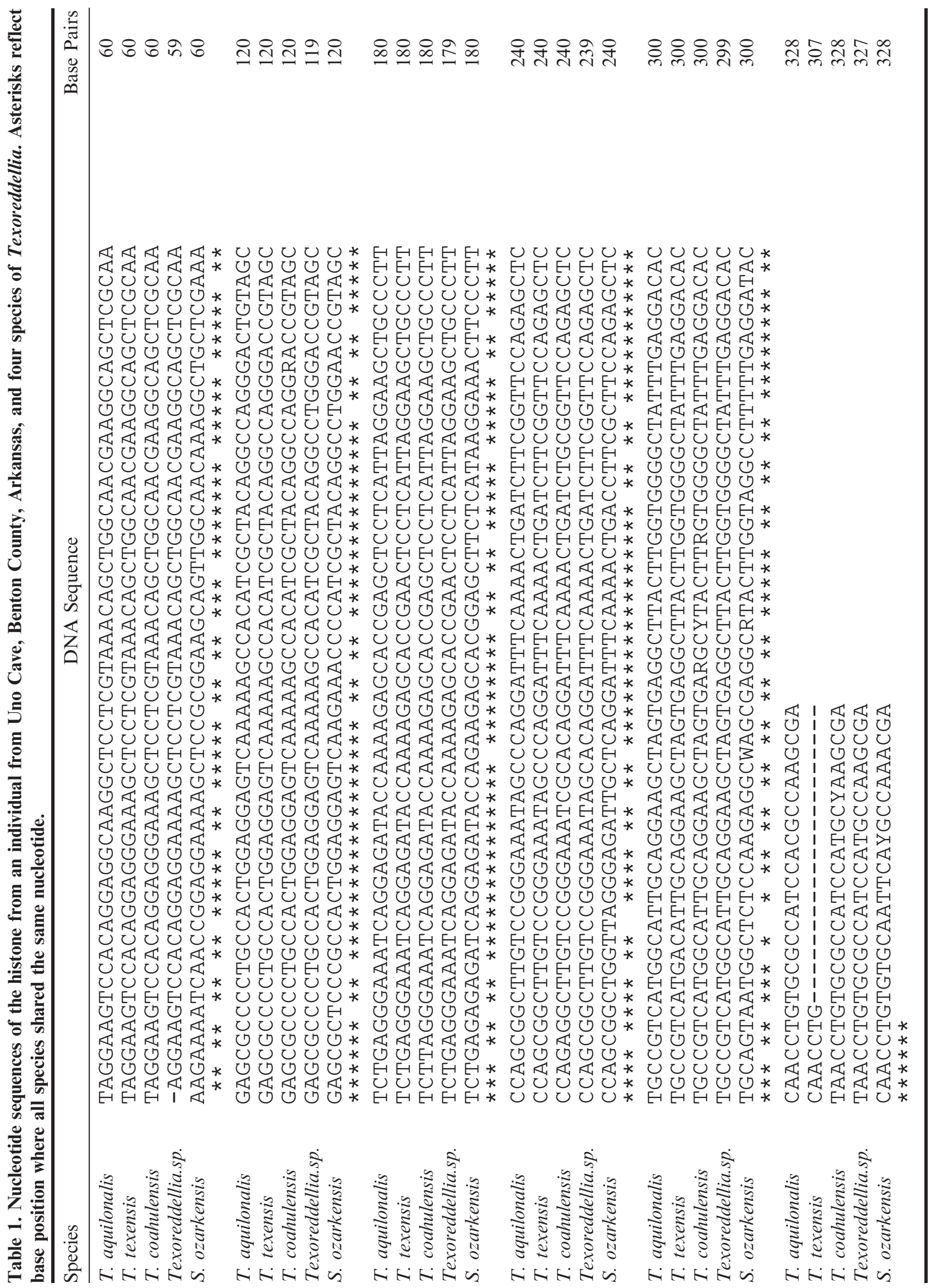




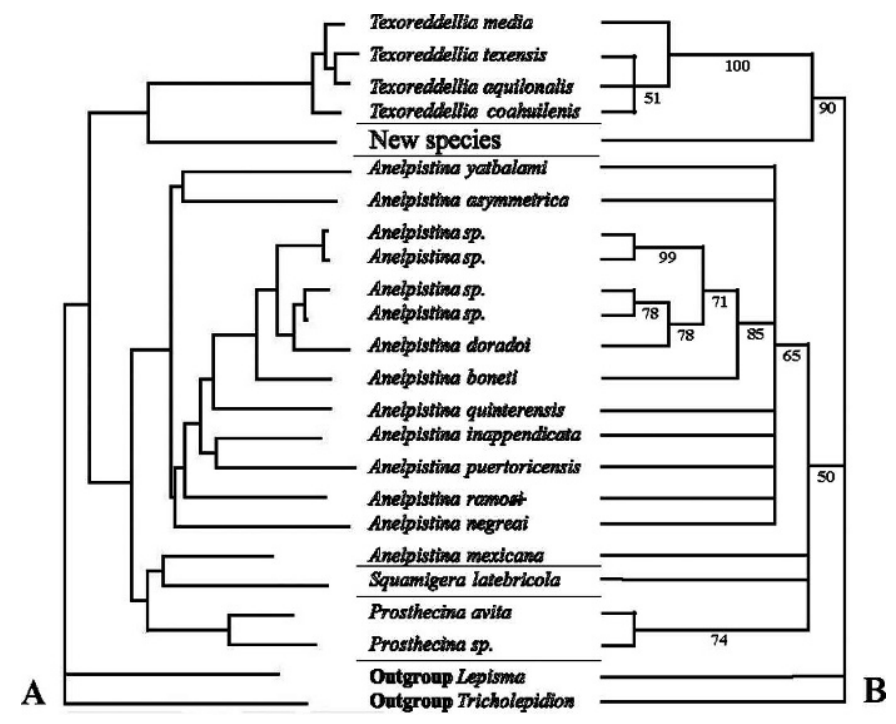

Figure 1. Distance and parsimony phylogram trees from histone-sequence data produced very similar topologies in which the new species is within a monophyletic group with Texoreddellia at the exclusion from other genera of the Cubacubaninae. A. Neighbor-joining; notice that the new species differs from the other species of Texorredellia by a distance equivalent to the differences found between the other genera Squamigera, Prostecina, and Anelpistina. B. Parsimony bootstrap 50\%-majority-rule consensus trees.

vesicle and very long and specialized chaetae, their length being half or more the width of the paramera.

Description: Pedicellus of adult male with unicellular glands and with a blade-like spine not too scleritized. Mouthparts not specialized. Mandible strongly sclerotized apically with usual teeth. Galea apically with sensory pegs. Lacinia heavily sclerotized distally. First process of lacinia pectinate. Labium without prominent lateral lobes.

Tarsi with four articles. Praetarsi with three simple claws. Median claw glabrous, slender, and smaller than lateral claws. Urosterna II-VII subdivided into two coxites and one sternite. Urosterna VIII and IX of male entire. Median portion of sternites with $1+1$ sublateral macrochaetae at hind borders, as well as $1+1$ macrochoetae near suture at about middle of segment. Coxites on segments II-IX with stylets. Eversible vesicles on segments II-VI, pseudovesicles on VII. Urosterna III and IV of adult males apparently without modifications. Urosternum VIII of male straight posteriorly, without emarginations or projections in between the stylets of this segment. Tergum $\mathrm{X}$ with several subequal macrochaetae on posterior angles.

Point of insertion of paramera apparently not too deep. Paramera with a distal semi-eversible vesicle, somewhat similar to Texoreddellia (Wygodzinsky, 1973). Specialized chaetae very long, their length being half or more the width of the paramera. Stylets IX apparently without spines in males as seen in some species of Prosthecina or in
Anelpistina mexicana, although some of the dorso-ventral macrochaetae may be scleritized. Opening of penis longitudinal. Cercus of male with sensory pegs. Appendix dorsalis without sensory pegs. Female with a subgenital plate.

Type species: Speleonycta ozarkensis, n. sp.

Etymology: From speliaon $=$ Greek for cave and nycta $=$ Greek for night. It references in Greek mythology the occupation of caves by Nyx, the primordial goddess of night.

Remarks: Speleonycta belongs to the Cubacubaninae (Mendes, 1988), characterized by subdivided abdominal sterna II-VII and fused coxites of abdominal segments VIII and IX. Speleonycta is distinguished from all other genera of this subfamily by the very long and specialized chaetae on the paramera. The type species of the new genus shares some characteristics with Texoreddellia, such as the paramera with semi-eversible vesicles, urosternum VIII of male straight posteriorly without emarginations or projections in between the stylets of this segment, and a blade-like spine in the pedicellus. None of these characteristics are present in any other of the genera of Cubacubaninae.

The new genus can easily be distinguished from Texoreddellia and Squamigera (Espinasa, 1999) by the absence of scales; from Allonicoletia (Mendes, 1992) by the presence of stylets on urosternite II; from Prosthecina (Silvestri, 1933) by the absence of conspicuous lateral lobes bearing numerous glandular pores in the submentum; from Anelpistina Silvestri, 1905 (= Cubacubana Wygodzinsky and Hollinger, 1977; syn. = Neonicoletia Paclt, 1979) as defined by Espinasa et al. (2007), by its urostenum VIII without emarginations or projections in between the stylets of this segment and its distinctive paramera.

Distribution: Specimens of this genus have been collected from Ozark caves in Arkansas and Oklahoma, and also from Arkenstone Cave, in Arizona, and Clough Cave, in California. The Arizona and California specimens are undescribed species currently under study. Specimens from both localities are clearly within the new genus, despite being geographically distant. Members of the new genus may actually have a wide distribution throughout the caves of the southern United States, despite being collected so sporadically.

Speleonycta ozarkensis Espinasa, Furst, Allen, AND SLAY

New Species (Figs. 2A-G, 3A-F, 4A-G)

Material: Holotype Oklahoma; Cherokee County, Single Barrel Cave ( ${ }^{\prime}$, body $\sim 11 \mathrm{~mm}$, tarsus $3^{\text {rd }}$ leg $1.35 \mathrm{~mm}, 7 / 28 / 05$, G. O. Graening and M. E. Slay col.). Paratypes: Arkansas; Benton County: Bear Hollow Cave (o, $9 \mathrm{~mm}$, no third leg, 12/7/00, M. E. Slay and G. O. Graening col.), and Uno Cave (o', body $11 \mathrm{~mm}$, tarsus third leg $1.35 \mathrm{~mm}, 12 / 2 / 05$, R. Rylee col.). Oklahoma; Delaware County: Black Hollow Cave (o, body $12 \mathrm{~mm}$, tarsus $3^{\text {rd }}$ leg $1.5 \mathrm{~mm}, 7 / 29 / 05$, G. O. Graening and M. E. Slay col.). All 
A new genus of the subfamily Cubacubaninae (Insecta: Zygentoma: Nicoletildae) from Caves in south-central and SOUTHWESTERN USA
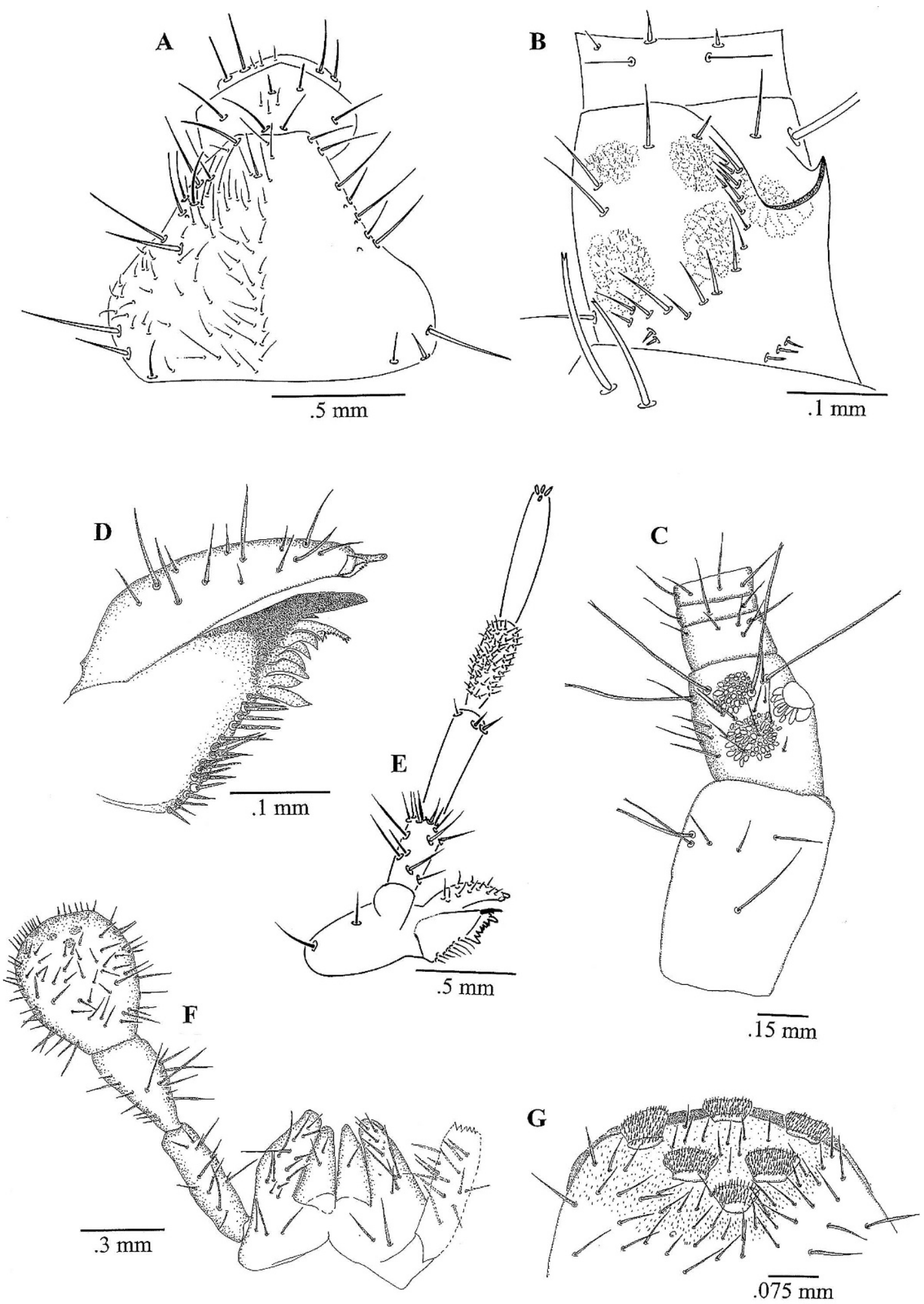

Figure 2. Speleonycta ozarkensis n. sp., male. Microchaetae partially shown. A, head. B, pedicellus. C, base of antennae. D, galea and lacinia. E, maxilla. F, labium. G, apex of labial palp. 


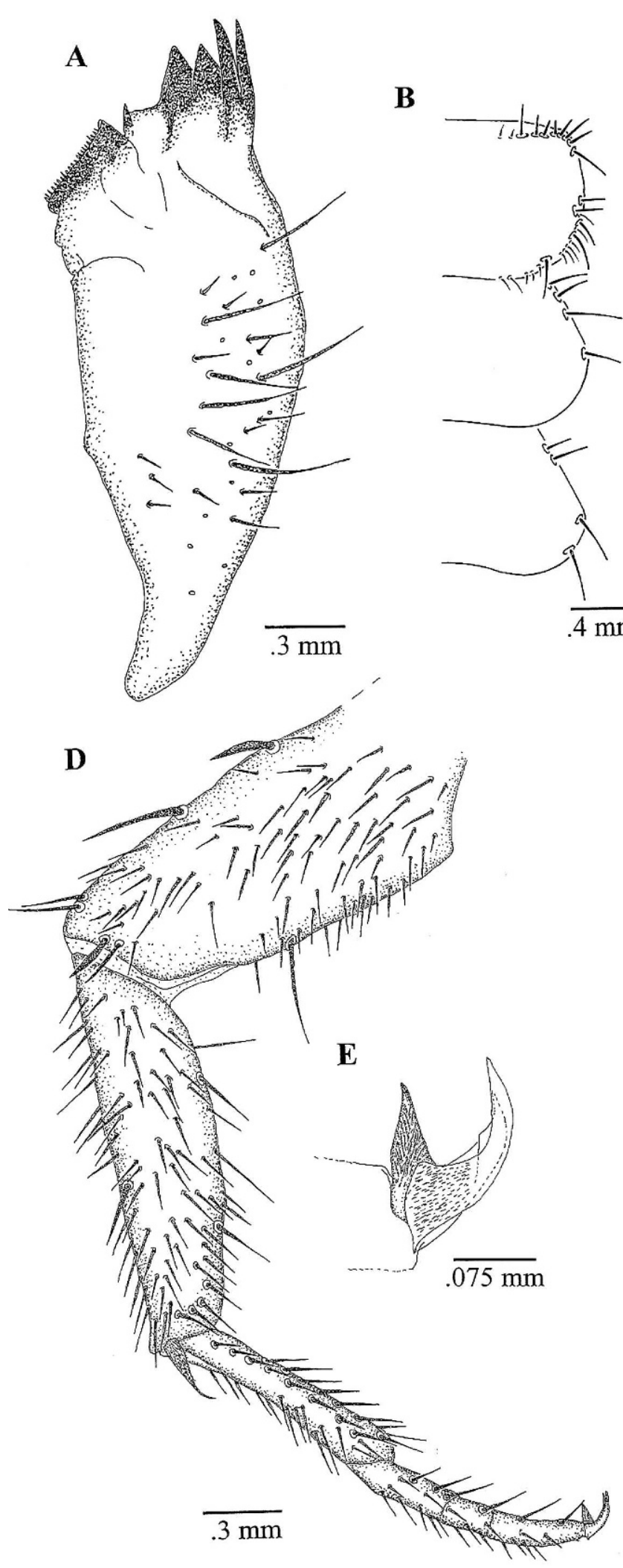

C
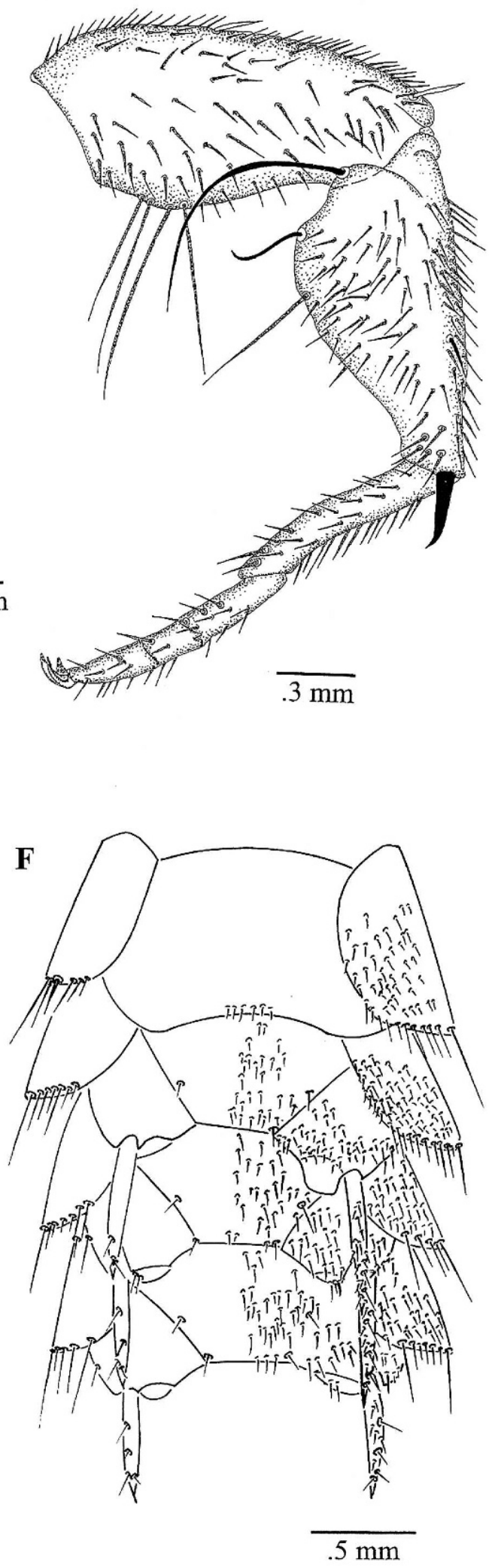

Figure 3. Speleonycta ozarkensis n. sp., male. Microchaetae partially shown. A, mandible. B, thoracic nota. C, second leg. D, third leg. E, claws and endopodium. F, urosterna I-IV. 
A new genus of the subfamily Cubacubaninae (Insecta: Zygentoma: Nicoletildae) from Caves in south-central and SOUTHWESTERN USA

A
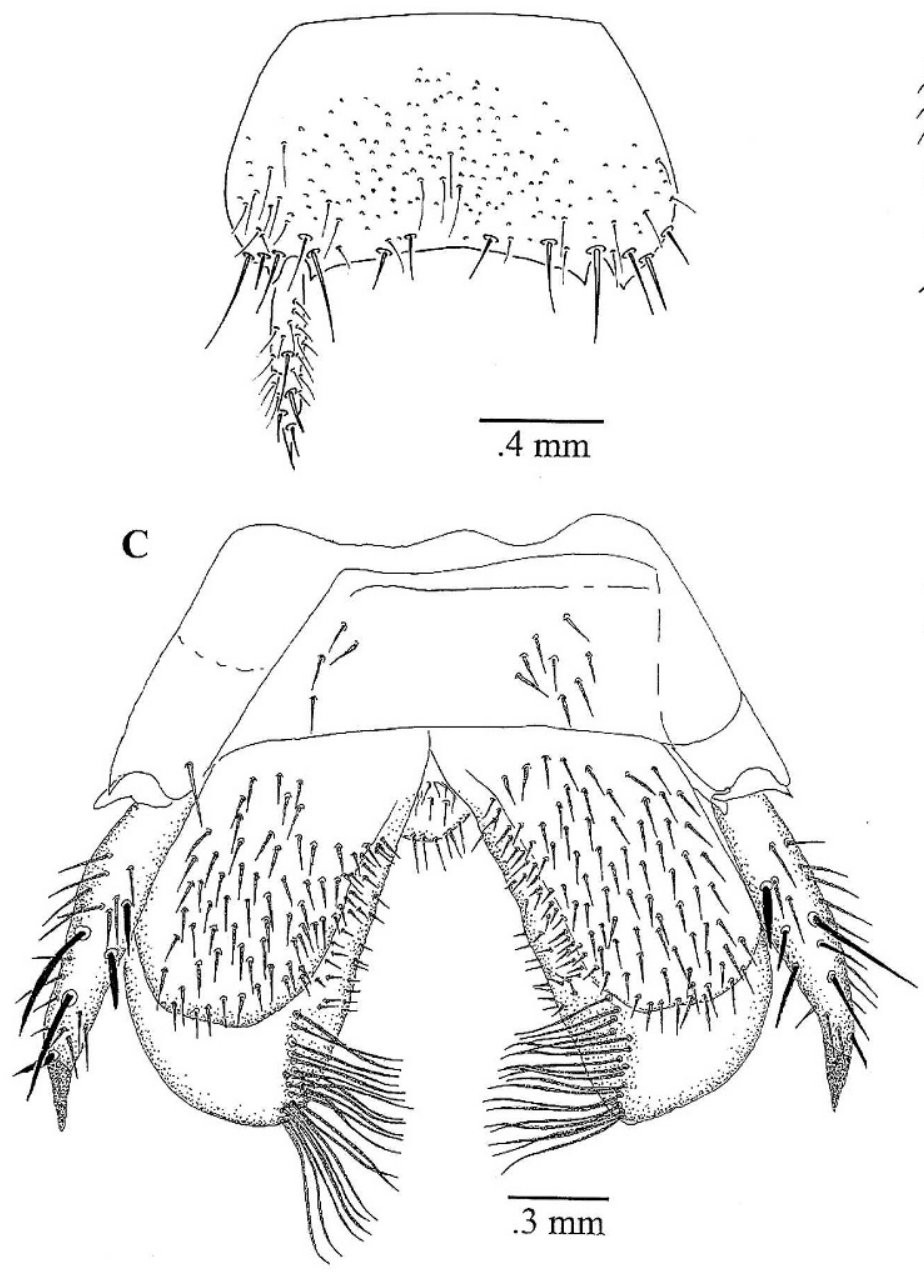

B

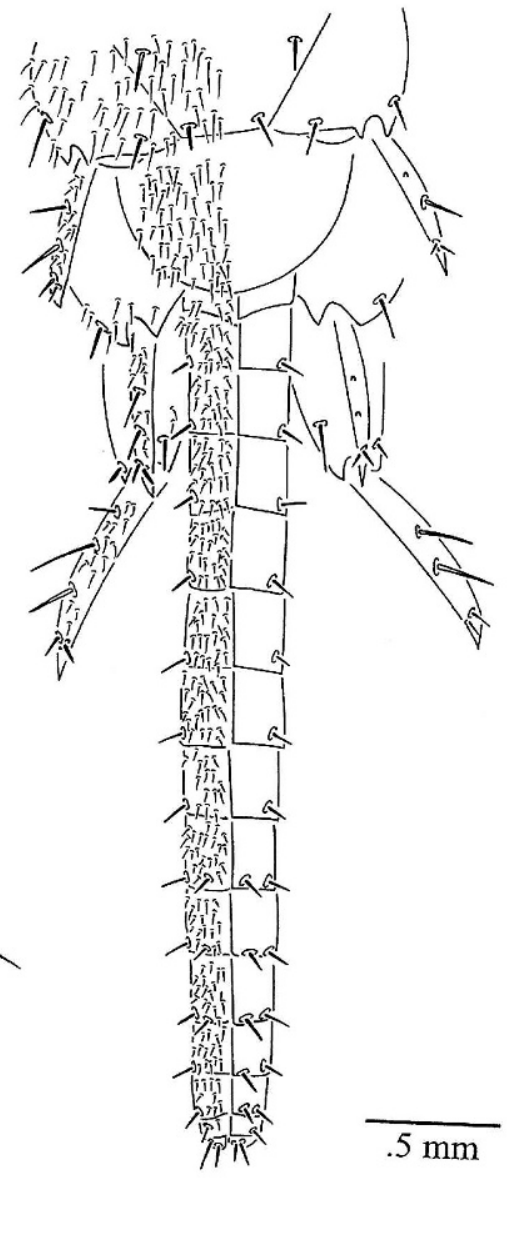

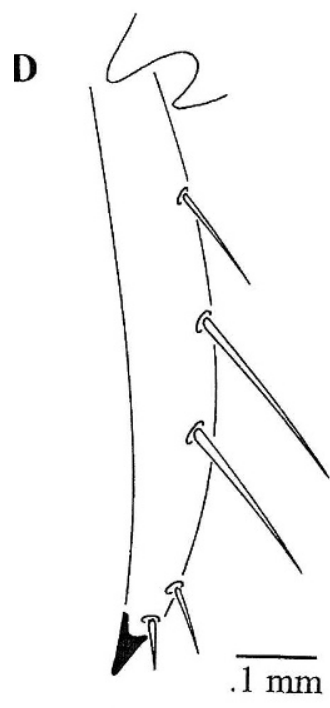
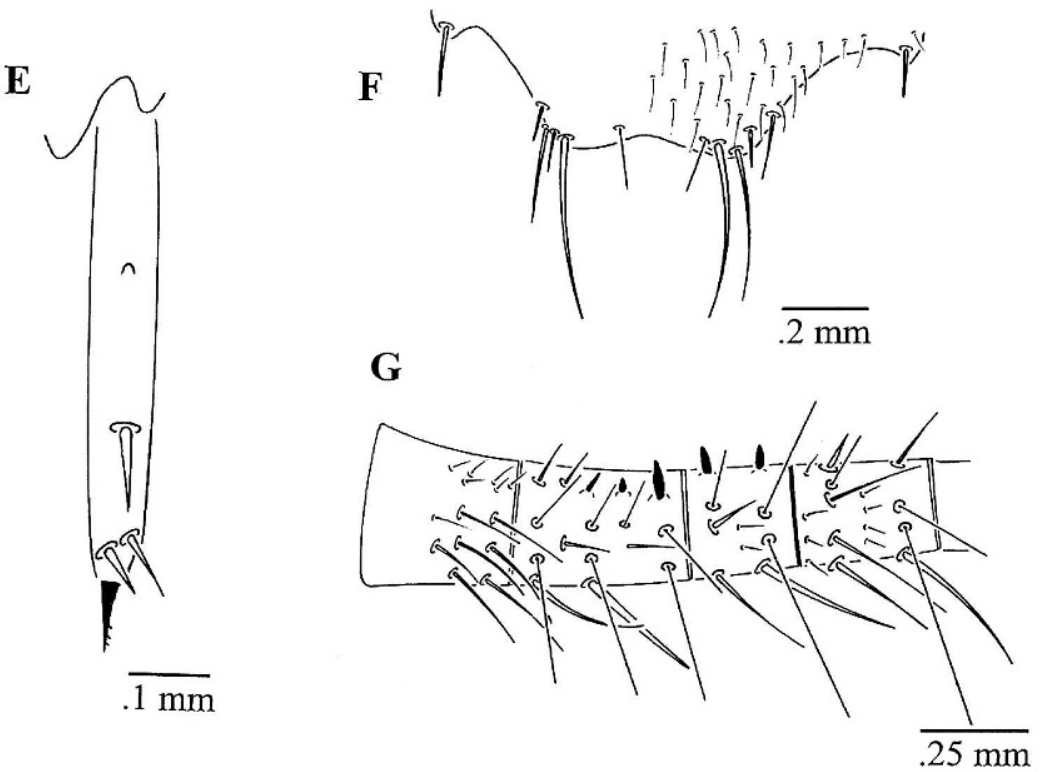

Figure 4. Speleonycta ozarkensis n. sp., A, C-G, male. B, female. Microchaetae partially shown. A, urotergum VIII. B, ovipositor. C, genital area. D, stylets IX. E, stylets VIII. F, uroterguite X. G, cercus. 
caves, despite multiple collecting trips, have yielded only a single individual.

Description: Maximum body length of samples $12 \mathrm{~mm}$. Antennae and caudal appendages broken in all specimens; their maximum conserved length was $1 \mathrm{~mm}$ and $0.5 \mathrm{~mm}$, respectively. General color light yellow to white.

Head with macrochaetae and microchaetae as shown in Figure 2A, with about eight macrochaetae on border of insertion of antennae. Pedicellus of male shorter than first article and with clusters of unicellular glands. Four ventral clusters are bordered with a not very conspicuous row of microchaetae forming a $U$, and on outer border, a bladelike spine not very sclerotized and with more unicellular glands at its base (Fig. 2B, C). Basal articles of antennae of female simple.

Mouthpart appendages short, especially when compared with other cave nicoletiid species. Maxilla as shown in Figures 2D and 2E. Last article 1.5 times longer than penultimate. Apex of galea with two conules, one longer than wide and the other wider than long (Fig. 2D). Two teeth on lacinia. Labial palp as in Figures $2 \mathrm{~F}$ and $2 \mathrm{G}$, apical article distinctly longer than wide and longer than the next to last article. Penultimate article with a not very distinct bulge containing two macrochaetae. Labium and first article of the labial palp with macrochaetae. Mandible chaetotaxy as in Figure 3A, with many macrochaetae. Pro-, meso-, and metanota with several macrochaetae on postero-lateral margins, apart from several setae of varied sizes (Fig. 3B). Legs of medium size, hind tibia approximately 3.5 times longer than wide and slightly shorter than tarsus (Fig. 3D). On male holotype, tibia of second leg very stout ( 2 times longer than wide) with a large bulge with 3 distinctly long, sclerotized, and curved macrochaetae (Fig. 3C). Female legs simple. Claws short and with a hairy appearance (Fig. 3E) similar to other Anelpistina (Espinasa et al., 2007).

Abdominal sterna as in Figure 3F. Urosternum III and IV without modifications. Posterior margin of urosternum VIII of male straight, without emarginations or projections in between the stylets of this segment (Fig. 4A). Urosternum IX of male as in Figure 4C. Point of insertion of paramera in urosternum IX slightly below level of base of the stylets of this segment (Fig. 4C). Base of internal faces of coxal processes with one slightly sclerotized macrochaeta (Fig. 4C). Penis and paramera as in Figure 4C. Paramera very stout, with a distal semi-eversible vesicle, somewhat similar to Texoreddellia (Wygodzinsky, 1973), and with long specialized macrochaetae. Paramera attain apex of stylets IX.

Stylets IX stout and without small teeth on robust terminal spine. Stylets IX larger than others, without sensory cones, but dorso-ventrally with sclerotized macrochaetae (Fig. 4C). Ventrally with about three macrochaetae and an extra subapical pair (Fig. 4D). Other stylets have a terminal spine with small teeth and with about two macrochaetae and an extra subapical pair (Fig. 4E).
Urotergite $\mathrm{X}$ protruding, shallowly emarginate in both sexes, posterior angles with several macrochaetae and a few relatively strong setae (Fig. 4F). Length of inner macrochaetae slightly longer than the distance between them.

Cercus of adult male straight, with several subequal annuli slightly longer than wide. Sensory pegs on second and third articles. Some pegs slightly bigger than others (Fig. 4G). Appendix dorsalis without sensory pegs. Female cercus and appendix dorsalis simple.

Subgenital plate of female rounded (Fig. 4B) to subparabolic. Ovipositor in largest adult female $(12 \mathrm{~mm})$ surpasses apex of stylets IX by 2 times the length of stylets (Fig. 4B). Gonapophyses with 15 or 16 annuli.

Postembryonic development: Both males were of same length $(\sim 11 \mathrm{~mm})$ and had similar development in pedicellus and genital area. The male from Uno Cave had neither second legs nor cerci, so it is unknown if the three distinct macrochaetae are present in the legs or the pegs on the cerci. In both females $(12 \mathrm{~mm}$ and $9 \mathrm{~mm})$, ovipositor surpassing apex of stylets IX by 2 times the length of stylets.

Etymology: ozarkensis; Derived from the word Ozarks, the region where the species was discovered.

Remarks and distribution: Other nicoletiid specimens have been collected from Newton County (Tweet's Cave 10/21/01 and Wolf Creek Cave 11/11/00) in Arkansas and Delaware County (McGee's Cave 8/31/01) in Oklahoma, but were not available for examination. It is likely they belong to the same species. If so, the seven caves with the new species span about 100 miles from the Ozark Plateau. It is likely that the species is endemic to the cave systems of this karstic area. Despite multiple collecting trips, all caves have yielded only a single individual. Specimens of the different caves are at different stages of their postembryonic development, as well as being either male or female. The scarcity of specimens per population makes it difficult to determine how much of the variability is due to variation among populations, rather than to species differences.

Until recent studies, multiple cave populations of Texoreddellia spanning over 200 miles of Texan karst were assumed to be all included within a single species. It was not until molecular data were available that it was established they are in reality a complex of at least six closely related species (Espinasa and Giribet, 2009). DNA sequences in the new genus are available for only a single individual of a single locality. Until more specimens can be collected or more molecular data obtained, the possibility that this species is actually a complex of closely related species remains open.

\section{ACKNOWLEDGMENTS}

We thank Nina Parker, chair of the Biology Department, Shenandoah University, for supporting the sequencing and the School of Science of Marist College for supporting the field expenses of one of us (SF) and the

Journal of Cave and Karst Studies, December 2010 •167 
publication of the manuscript. We thank Steve Hensley and Richard Stark (Oklahoma United States Fish and Wildlife Service), Bill Puckett (Poteau Public School District), Rhea Rylee (Arkansas United States Forest Service), The Nature Conservancy (Oklahoma Field Office, Arkansas Field Office), and several private landowners for facilitating and allowing access to these sites and others to look for additional specimens. Additional funding was provided by United States Fish and Wildlife Service (Oklahoma and Arkansas), United Stated Forest Service (Arkansas), Arkansas Game and Fish Commission, and The Nature Conservancy.

\section{REFERENCES}

Espinasa, L., 1999, A new genus of the subfamily Cubacubaninae (Insecta: Zygentoma: Nicoletiidae) from a Mexican cave: Proceedings of the Biological Society of Washington, v. 112, no. 1, p. 52-58.

Espinasa, L., Flick, C., and Giribet, G., 2007, Phylogeny of the American silverfish Cubacubaninae (Hexapoda : Zygentoma : Nicoletiidae): a combined approach using morphology and five molecular loci: Cladistics, v. 23, no. 1, p. 22-40.

Espinasa, L., and Giribet, G., 2009, Living in the dark - species delimitation based on combined molecular and morphological evidence in the nicoletiid genus Texoreddellia Wygodzinsky, 1973 (Hexapoda: Zygentoma: Nicoletiidae) in Texas and Mexico, in Cokendolpher, J.C., and Reddell, J.R., eds., Studies on the Cave and Engogean Fauna of North America, Part V, Austin, Texas Memorial Museum Speleological Monographs 7, p. 87-100.

Mendes, L.F., 1988, Sur deux nouvelles Nicoletiidae (Zygentoma) cavernicoles de Grèce et de Turquie et remarques sur la systématique de la famille: Revue Suisse de Zoologie, v. 95, no. 3, p. 751-772.

Mendes, L.F., 1992, Novos dados sobre os tisanuros (Microcoryphia e Zygentoma) da América do Norte: Garcia de Orta Serie de Zoología, v. 16 , no. $1-2$, p. $171-193$.

Paclt, J., 1979, Neue Beiträge zur Kenntnis der Apterygoten-Sammlung des Zoologischen Instituts und Zoologischen Museums der Universität Hamburg. VI. Weitere Doppel- und Bortenschwänze (Diplura: Campodeidea: Thysanura: Lepismatidae und Nicoletiidae): Entomologische Mitteilungen aus dem zoologischen Museum Hamburg, v. 6, no. 105 , p. $221-228$.

Silvestri, F., 1905, Materiali per lo studio dei Tisanuri. VI. Tre nuove specie di Nicoletia appartenenti ad un nuovo sottogenere: Redia (Firenze), v. 2, p. 111-120.

Silvestri, F., 1933, Nuovo contributo alla conoscenza dei Tisanuri del Messico: Bolletino del Laboratorio di Zoología general e agraria di Portici, v. 27, p. 127-144.

Ulrich, C.J., 1902, A contribution to the subterranean fauna of Texas: Transactions of the American Microscopical Society, v. 23, p. 83101.

Wygodzinsky, P., 1973, Description of a new genus of cave Thysanuran from Texas (Nicoletiidae, Thysanura, Insecta): American Museum Novitates, no. 2518, p. 1-8.

Wygodzinsky, P., and Hollinger, A.M., 1977, A study of Nicoletiidae from Cuba (Thysanura), in Orghidan, T., Núñez Jiménez, A., Decou, V., Negrea, Şt., and Viña Bayés, N., eds., Résultats des Expéditions Biospéleologiques Cubano-Roumaines à Cuba, volume 2, Bucharest, Editura Academiei Republii Socialiste România, p. 317-324. 